\title{
ДЕЯТЕЛЬНОСТЬ ОРГАНОВ ВНУТРЕННИХ ДЕЛ РОССИЙСКОЙ ФЕДЕРАЦИИ И МЕЖДУНАРОДНОЕ IIPABO
}

\author{
Е.Г. Ляхов, М.Н. Кузьмина*
}

Деятельность органов внутренних дел в последнее время стала предметом исследований не только в административном, уголовном, уголовно-процессуальном праве, но и в работах по истории, теории права и государства. В связи с переоценкой приоритетов, признанием в качестве высшей ценности человека, его прав и свобод деятельность органов внутренних дел приобретает новый характер. Ее направленность на защиту законности, прав и свобод человека и гражданина, борьбу с преступностью обусловливает необходимость разработки системы и содержания правовых и международно-правовых основ формирования и деятельности органов внутренних дел.

В правовую систему нашего государства входят общепризнанные принципы и нормы мехдународного права, международные договоры (ч. 4, ст.15, Конституции РФ). В связи с этим становится актуальным вопрос об их юридической силе и месте среди внутригосударственных нормативно-правовых актов. Является настоятельной необходимостью исследование вопросов применения органами внутренних дел общепризнанных принципов и норм международного права, положений международных договоров, в частности о правовой помощи, консульских конвенций, договоров о борьбе с преступностью или ее отдельными проявлениями.

\section{1. Правовые основы формирования и деятельности органов внутренних дел как снстема}

Правовые основы формирования и деятельности органов внутренних дел - это совокупность начал, выраженных в различных формах, в соответствии с которыми строится и функционирует система органов внутренних дел. Нормативно-правовые основы представляют собой совокупность нормативно-правовых ахтов, которые являются основной, но не единственной составляющей исследуемого объекта. Правовые основы формирования и дея-

*Ляхов Евгений Григорьевич - профессор Юридического института МВД России, Кузьмина Маргарита Николаевна - адъюнкт того же института. 
тельности органов внутренних дел представляют собой систему, характеризуюшуюся структурностью, целостностью, иерархичностью и взаимозависимостью. В Российской Федерации создан правовой материал, соответствующий общеправовым принципам и достаточный для системного рассмотрения данных правовых основ, существует определенный уровень правосознания и развития системы правоотношений внутри и вне системы органов внутренних дел. Рассматриваемая система состоит из следующих элементов: Конституция Российской Федерации, общепризнанные принципы и нормы международного права, международные договоры, федеральные законы, конституции и уставы, законы субъектов федерации, указы Президента и постановления Правительства Российской Федерации, постановления Конституционного Суда и Верховного Суда России, ведомственные нормативные акты, издаваемые Министерством внутренних дел и имеющие нормативно-правовой хаpaxтер.

Важнейшим системообразуюшим элементом является Конституция Российской Федерации, содержащая достаточно положений, определяющих принципы деятельности и построения системы органов внутренних дел. В качестве структурных элементов выступают законы, непосредственно регулируюшие деятельность органов внутренних дел, иные конституционные и федеральные законы, кодификационные акты. Конституции, уставы и законы субъектов федерации являются правовой основой формирования и деятельности органов внутренних дел, когда устанавливают порядок организации подразделений, созданных за счет средств собственных бюджетов. Они не могут устанавливать новые нормы права, а регулирование деятельности муниципальной милиции должно идти в русле федерального законодательства, что обусловлено качеством Министерства внутренних дел ках федерального органа. Постановления Верховного Суда, воздействуя на правосознание (путем разъяснений и толкований законодательных норм), способствуют более эффективной реализации положений правовых основ. Постановления Конституционного Суда изменяют законодательные акты, когда лишают юридической силы правовые нормы, признанные неконституционными, и таким образом влияют на состояние системы правовых основ формирования и деятельности органов внутренних дел. Нормативно-правовые акты Министерства внутренних дел являются обширной и подвижной структурной частью системы, призванной обеспечивать должную реализацию нормативно-правовых предписаний.

Системе правовых основ формирования и деятельности органов внутренних дел присуши целостность и свойство внутреннего саморазвития. Целостность исследуемой системы в значительной сте- 
пени страдает от слабого знания сотрудниками органов внутренних дел захонов, норм мехдународного права, неприменения соответствующих правовых норм. В правоприменительной деятельности отрицательную роль играет низкий уровень правосознания сотрудников органов внутренних дел: соответствующие правоотношения искажаются, применяется авторитарный метод. Это создает большой разрыв между нормативно-правовыми установлениями и их реальным воплощением. Для обеспечения целостности системы и эффективной реализации правовых норм в конкретных правоотношениях необходимо поднять на более высокий уровень правосознание сотрудников органов внутренних дел, зачастую находящееся на грани обыденного.

Иерархичность системы правовых основ формирования и деятельности органов внутренних дел выражается в том, что каждый структурный элемент занимает строго установленное место. Верховенством по отношению ко всем остальным элементам обладает Конституция России. Постановления Верховного Суда и Конституционного Суда являются обязательными при реализации конкретных правоотношений и особое влияние оказывают на правосознание. Ведомственные нормативные акты регулируют внутриведомственные вопросы (исключение составляют делегированные акты внешнего действия). Взаимозависимость структурных частей правовых основ прослеживается по ряду параметров: общеправовое взаимодействие Конституции и иных законов; взаимодействие законов и ведомственных актов; законов и постановлений высших судебных органов. Не следует принихать значение имплементации ведомственных актов, ибо в конечном итоге от качества ведомственных нормативных актов и правильной их реализации зависит эффективность и законов, и Конституции.

\section{2. Соотношение и взаимодействие норм внутригосударственного и международного права}

В соответствии с ч.4, ст.15, Конституции Российской Федерации структурным элементом исследуемых основ становятся общепризнанные принципы и нормы международного права. В дальнейшем они будут играть все большую роль в деятельности органов внутренних дел, что обусловливает также необходимость дальнейшей теоретической разработки проблемы соотношения внутритосударственного и международного права.

Внутригосударственная нормативная база, взаимодействуя с нормами мехдународного права, испытывает все более возрастающее влияние с его стороны на различные аспекты функционирова- 
ния государственного аппарата и деятельность конкретных государственных органов. Проблема взаимодействия международноправовых и внутригосударственных норм носит не только технико-юридический, но и общетеоретический характер. Национальные правовые системы и мехдународное право имеют как общие, так и отличительные черты, взаимосвязаны друт с другом и оказывают друг на друта взаимное влияние. Наличие их общих черт обусловлено их единой социальной природой - все они являются способом выражения, существования правовой материи, в центре их должны быть человек, его права и свободы. Различия же происходят из того, что в каждой стране складывается собственная экономическая, политическая и социальная структура, свой уровень культуры и собственные традиции. Некоторые из этих слагаемых, ббладая определенной специфичностью и охазывая влияние на свойства правовой системы, придают ей такие черты, которые выделяют ее в особую, только этой стране присущую систему.

Соотношение и взаимодействие международного и внутригосударственного права - это соотношение и взаимодействие явлений надстроечного харахтера, природа и содержание которых определяются в конечном счете соответствующими базисными общественньми отношениями ${ }^{1}$.

Уже в конце XIX и в начале XX века некоторые ученые - М.H. Коркунӧв, П.Е. Казанский, Л.А. Камаровский - начинают не только рассматривать взаимодействие и взаимовлияние исследуемых правовых систем, но и отмечать особую роль международного права. Л.А. Камаровский указывал, что задача мехдународного права заключается в том, чтобы жизнь и отношения отдельных государств, на которые распадается человечество, поставить на юридическую почву, отыскать нормы права для их регулирования и через это обеспечить возможно прочный мир на земле; не вечный мир, о котором мечтако идеалисты, но мир юридически организованный и охраняемый².

Приоритет международного права, признаваемый в настоящее время большинством государств, вытекает, во-первых, из признания приоритета общечеловеческих ценностей над всеми другими, во-вторых, из экономических факторов: создания мирового рынка с международным разделением труда и возможности дальнейшей жизни на планете вообще лишь при приложении усилий всеми государствами, так ках наличие средств массового уничтожения и существование угрозы реальной экологической катастрофы ставят под вопрос само существование человека. Поэтому развитие мехдународного права, как и других категорий надстройки, определяется в конечном итоге закономерностями общественного развития. 
Те принципы и нормы международного права, в том числе установленные договором, которые соответствуют закономерностям общественного развития и, следовательно, являются прогрессивными, могут рассчитывать на то, чтобы закрепиться в международном праве ${ }^{3}$.

Влияние национального права на международное право осуществляется через разработку и принятие международных договоров, через внешнюю политику государств. Иногда абсолютно определенные законодательные акты государств оказывают влияние на развитие норм мехдународного права, если они являются прогрессивными и дают толчок дальнейшему поступательному развитию международных отношений. Примером могут быть Билль о правах 1689 года (Англия), Декларация независимости США 1776 года, Декларация прав человека и грахданина 1789 года (Франция). Являясь государственными законодательными актами, они, тем не менее, заложили фундамент института признания прав человека. Выраженные в них идеи нашли в XIX веке свое отражение в международно-правовых документах, касающихся вопросов установления прав и свобод, а Всеобщая декларация прав человека, принятая Организацией Объединенных Наций 10 декабря 1948 г., включает наиболее прогрессивные положения французской Декларации прав человека и гражданина. Влияние международного права на национальное носит преимуцественно непосредственный характер: нормы ратифицированных государством международных договоров являются основанием появления новых норм национального права, отмены или изменения старых.

Национальное и международное право - результат воли государства с тем отличием, что в международном праве государство участвует в выработке норм как один из равноправных субъектов, а в национальном законодательстве - внутригосударственные нормы представляют собой продукт волеизъявления самого государства. Основные черты этого единства - связанность через воли государств и общности - представляют собой государственно-волевые нормативные системы ${ }^{4}$. Общие свойства названных правовых систем обусловливают возможность рассмотрения проблем их соотношения, а особенные черты дают право говорить об их взаимодействии, понимаемом ках «всеобщая форма связи тел и явлений, выражающаяся в их взаимном влиянии друг на друга и изменении» 5 .

Все большее значение придается общим интересам государств, значительно изменились качественно и сами международные отношения. О моральности своей политики вынуждены думать все государства. Сила объективных законов общественного развития, 
невиданный ранее рост общественного мнения и народной дипломатии ведут $\mathbf{x}$ тому, что моральные нормы все более и более становятся неотъемлемой частью международных отношений 6 . Для нашего государства переход на новый уровень отношений произошел с момента провозглашения так называемого нового политического мышления как идеологической платформы в осуществлении страной внешней политики. Значительное снижение напряженности в мире, улучшение международных отношений явились результатом этой политики как бы в подтверждение мнения Л.А. Камаровского: «Не подлежит сомнению, что никахое прочное улучшение мехдународных сношений немыслимо без поднятия уровня, как в правителях, так и в народах, политической нравственности»?.

Международные нормы о правах человека влияют не только на национальное право государств-участников, но и показывают отношение к правам человека стран-неучастников соглашений, которые под давлением большого политического и морального авторитета этих документов будут стремиться привести внутреннее законодательство в соответствие $\mathrm{c}^{-}$общепризнанными нормами международного права в области прав человека. В международном праве можно выделить как правовые акты, обладающие юридической силой, так и нормативные акты, обладающие морально-политическим авторитетом, например резолюции Генеральной Ассамблеи ООН. Г.К. Дмитриева отмечает, что не только содержание и осуществление международно-правовых норм тесно связано с предписаниями морали, но и сам факт участия в договоре может предписываться нормами морали и иметь более или менее серьезные последствия ${ }^{8}$.

Для СССР принятие в 1989-1990 годах многих международных актов, касающихся вопросов защиты прав человека, послужило повышению авторитета государства на международной арене. Так, присоединение $\mathrm{K}$ Факультативному протоколу Международного пакта о гражданских и политических правах, давшее гражданам страны возможность подавать частные жалобы на свое государство в Комитет по правам человека, не только расширило правовой статус граждан СССР, но и подтвердило стремление государства построить действительно демократический строй. Ибо «нарушение прав человека "у себя дома" - почти безошибочное свидетельство агрессивного внешнеполитического курса и наоборот»'. Кроме того, это влияет на развитие процесса проникновения в правосознание людей идеи единства внутренней и международной законности, которая отражает углубляющееся единство человечества и его суде ${ }^{\text {to. }}$. 
Согласно II. 4 cr. 15 Конституции Российской Федерации, нормы мехдународного права, определяющие правовой статус человека, наряду с другими международными нормами являются частью правовой системы нашего государства. Это принципиально новое положение, так $\operatorname{xax}$ ранее наше государство - СССР утверждало, что хотя оно и признает обязательность Устава ООН, но регулирование прав человека относится $\mathbf{k}$ внутренней компетенции государства и вторжение в эту сферу является нарушением государственного суверенитета. По этому вопросу государства до сих пор придерживаются различных точек зрения. Эти вопросы решаются в зависимости от соотношения различных политических сил внутри страны, их позиций, а также других факторов, а не только от существования международных договоренностей. Все это отражается во внутреннем законодательстве, которое определяет, каким образом и в хакой объеме государство будет выполнять взятые на себя международные обязательства ${ }^{11}$. Задача российского государства - создать такой демократический порядок в стране, который, с одной стороны, будет способствовать максимальному расширению прав и свобод человеха, используя международные нормы, а с другой - эффективно охранять их. В конечном счете стабильность, незыблемость содержания правового статуса членов общества - это стабильность и сила общества, а значит, и устойчивость государства, ибо «там, где государственная власть оказывается не в состоянии обеспечить каждому личную и имущественную безопасность, наступает опасный для государства момент - у населения мохет возникнуть сомнение в необходимости самого государства» ${ }^{12}$.

Однако признание международно-правовых норм частью правовой системы страны ставит массу вопросов: каким образом следует применять эти нормы, имеют ли они прямое действие и кахой уровень в системе законодательства занимают? Причем в процессе правоприменения сразу же выявляется, что даже при конституционном захреплении применения в коллизионных вопросах норм международного права проблема не всегда может быть разрешена так просто, так как введение международной нормы в сложившуюся систему может повлечь рассогласование норм используемой отрасли (или отраслей) национального права. Следовательно, становится необходимым согласование соответствующих международных норм и целых институтов или даже отраслей национального права. 


\section{3. От общетеоретнческих рассухдений - к практике имплементации норм мехдународного права}

Проблема имплементации международно-правовых норм во внутригосударственное законодательство является сложной. Чаще всего даже при закреплении в Конституции положения о включении мехдународно-правовых норм в национальную правовую систему эти нормы не действуют вне механизма, определяющего их действие внутри государства. Это вызвано не только недостаточной сориентированностью на взаимодействие с международным правом национально-правовой системы, но неподготовленностью многих норм международного права $K$ непосредственному их применению. Международное право еще не кодифицировано в должной мере. Его нормы недостаточно конкретно сформулированы, напоминая зачастую декларации о намерениях. А нередки и случаи, когда норма вырахает поверхностный компромисс, а не согласие в отношении четкого правила ${ }^{13}$. Международные нормы имеют преимущество перед внутренними законами, хотя и занимают тот же законодательный уровень. Находясь на одной «ступени», они обладают различной с законами юридической силой. И нормы внутренних захонов, и нормы мехдународного права должны подчиняться конституционным положениям, но имплементированная норма имеет большую силу, чем обычная законодательная. Если принять другое, то мы окажемся перед фактом: нормы впоследствии изданного внутреннего закона смогут изменить или отменить вовсе нормы мехдународного договора, что совершенно недопустимо в силу принципа добросовестного исполнения обязательств.

Закон «О международных договорах Российской Федерации» от 16 июня 1995 r. $^{14}$ устанавливает, что положения официально опубликованных мехдународных договоров, не требующих издания внутригосударственных актов пля применения, действуют в Российской Федерации непосредственно, а для осуществления иных положений международных договоров принимаются соответствующие правовые акты (ст.5). Некоторые мехдународные договоры прямо предусматривают обязанность государств принять определенные законодательные меры для реализации их норм. Так, Международный пахт об экономических, социальных и культурных правах предусматривает, что участвующие в нем государства обязуются осуществлять провозглашенные в Пакте права лишь в «максимальных пределах имеющихся ресурсов» путем соответствующих «законодательных мер». Международная конвенция о ликвидации всех форм расовой дискриминации налагает на государства-участники обязательство объявить караемым по закону преступлением 
распространение идей, основанных на расовом превосходстве, а также установить утоловную ответственность за участие в расистских организациях (ст. 4) ${ }^{\text {is. }}$ Закон, подтверждая, что международные договоры, наряду с общепризнанньми принципами и нормами международного права, в соответствии с Конституцией являются составной частью правовой системы Российской Федерации, устанавливает, что в случае коллизий между положениями международного договора и внутреннего закона применяется норма международного договора. Следует отметить, что это правило не всегда является обязательным. Например, если в национальном законе предусмотрены более благоприятные положения, то они применяются, несмотря на то что международным договором это правило не предусмотрено или предусмотрено в меньшем объеме. Такие нормы содержатся в Международном пакте о гражданских и политических правах (ч. 2, ст. 5) Конвенции о правах ребенка (ст. 41) ${ }^{16}$. Наделение правами и наложение обязанностей для выполнения конхретного договора - дело государства, предусматривающего их для своих органов и должностных лиц. Подтверждают это и нормы национального права. Так, ст. 32 Закона гласит: «Президент Российской Федерации и Правительство Российской Федерации принимают меры, направленные на обеспечение выполнения международных договоров Российской Федерации». Далее предусматривается, что федеральные органы исполнительной власти, в компетенцию которых входят вопросы, регулируемые международными договорами Российской Федерации, обеспечивают выполнение обязательств российской стороны по договорам и осуществление прав Российской стороны, вытекающих из этих договоров, а также наблюдают за выполнением другими сторонами договоров их обязательств.

Большинство универсальных международных договоров были ратифицированы СССР и, следовательно, являются обязательными для России ках его правопреемницы. В настоящее время у России в международно-правовой области существует более 300 многосторонних и двусторонних соглашений, регулируюших тахже и вопросы борьбы с преступностью, 100 из хоторых непосредственно затрагивают интересы Министерства внутренних дел. Как правопреемница СССР Россия является участницей около 30 универсальных договоров о борьбе с отдельными видами преступлений.

В отношении общепризнанных принципов и норм международного права следует исходить из их всеобщности, постоянства фактической и законодательной практики государств, ведущей $\mathbf{k}$ их созданию, единообразия применения. В качестве таких принципов и норм могут признаваться международные обычаи, декларации Генеральной Ассамблеи ООН и других международных организа- 
ций (например, Всеобщая декларация прав человека), решения международных судебных и арбитражных органов, а также общие принципы права, признаваемые нациями. В качестве общепризнанной нормы признаются и нормы международных договоров, к которым пока не присоединилось посударство, но которые являются общепризнанными. Последние могут выступать как в виде правовых норм, так и в виде правовых обычаев. Конституция не говорит o преимущественном применении общепризнанных принципов и норм международного права перед национальными нормами в случае коллизии, подчеркивая лишь, что права человека признаются и гарантируются согласно общепризнанным принципам и нормам международного права (ч.1, ст.17). Но Закон «О международных договорах РФ» 1995 года впервые определил равную юридическую силу договорных и обычных норм. Поэтому, учитывая, что формой выражения общепризнанных принципов и норм зачастую служит обычай, можно предположить, что гражданин вправе ссылаться на эти положения в обоснование прав и свобод при отсутствии таких правоустановлений во внутригосударственном законодательстве.

Для органов внутренних дел обязательными являются все международные межгосударственные договоры, заключенные Российской Федерацией и прошедшие процедуру ратификации. Это Международные пакты о правах человека, Конвенция против пыток и других жестоких, бесчеловечных или унижающих достоинство видов обращения и нахазания 1984 года, Женевские конвенции о защите прав человека в период вооруженных конфликтов и Дополнительные протоколы к ним, Конвенция о правах ребенка 1989 года и др. Деятельность органов уголовной юстиции может основываться и на ряде международных соглашений, направленных на борьбу с военными преступлениями и преступлениями против человечества: Конвенции о ликвидации всех форм расовой дискриминации 1966 года, Конвенции о предупреждении преступления геноцида и наказании за него 1948 года, Конвенции о преступлении апартеида и наказании за него 1973 года и др. Существует также много международных документов, регулирующих определенные сферы деятельности правоохранительных органов либо определенные виды преступных деяний. Это Конвенция 0 предупреждении и наказании преступлений против лиц, пользующихся международной защитой, 1973 года, Единая конвенция о наркотических средствах 1961 года, Конвенция о физической защите ядерного материала 1978 года, Международная конвенция о борьбе с захватом заложников и многие другие. В качестве обязательного документа следует также назвать Всеобшую декларацию прав человека 1948 года, являющуюся примером общепризнанной нормы международного права. 


\section{4. Особое место договоров о правовой помощи \\ в правовых основах ортанов внутренних дел}

Детально разработанными и регулирующими целый круг вопросов в области деятельности органов уголовной юстиции являются договоры о правовой помощи и правовых отношениях. Эти договоры после их ратификации действуют для органов договаривающихся сторон непосредственно, взаимодействне Министерства внутренних дел России с органами юстиции или иными компетентными органами государства сторонами договора осуществляется обычно через Генеральную Прокуратуру Российской Федерации и дипломатические службы. Могут устанавливаться и прямые контакты - между министерствами внутренних дел стран Содружества Независимых Государств. Некоторые права для иностранных граждан предусматриваются в консульских конвенциях, договорах $\checkmark$ торговом судоходстве.

Подавляюшее холичество норм мехдународных договоров о правовой помощи и правовых отношениях имеют процессуальный характер и создают юридическую основу для развития непосредственного сотрудничества между органами уголовной юстиции, упрошают порядок сношений и позволяют этим органам действовать более быстро и слаженно. Основными условиями соблюдения договорных положений являются: а) взаимность; б) ненарушение суверенитета запрашиваемого государств исполнением просьбы; в) ненанесение охазанием правовой помощи ушерба безопасности государства.

На февраль 1996 года Россией заключено 28 договоров о правовой помощи (в том числе заключенных СССР и действующих для России как его правопреемницы), 30 межправительственных договоров о борьбе с преступностью и ее отдельными проявлениями, в частности с Узбекистаном, США, Швецией. МВД имеет 50 межведомственных договоров, 14 многосторонних и 12 двусторонних договоров со странами СНГ по вопросам оперативного и другого сотрудничества по вопросам борьбы с преступностью, 18 договоров с правоохранительными министерствами зарубежных стран ${ }^{17}$.

Начало заключению договоренностей о правовой помощи положили Гаагские конвенции по гражданскому процессу 1905 и 1954 годов, которые, хотя и не касались вопросов деятельности органов уголовной юстиции, устанавливали порядок выполнения поручений иностранных судов. Так, например, ст.6-16 Гаагской конвенции 1905 года предусматривали случаи отказа в исполнении поручения: а) если подлинность документа вызывает сомнения; б) если исполнение поручения в запрашиваемом государстве не относится к компетенции судебных органов; в) если, по мнению этого 
государства, исполнение поручения могло бы нарушить его суверенитет или угрожало бы его безопасности.

Договоры о правовой помощи, несмотря на различия в наименованиях, в основном однотипны, хотя и регулируют более узкий или более широких круг вопросов. Это обусловлено тем, что в разных странах под правовой помощью понимается разинчный объем процессуальных действий. Понятие «правовая помощь» в договорах не выработано и точного перечня действий, осуществляемых в порядке ее оказания, не дано.

В отношениях стран Содружества Независимых Государств вопросы охазания правовой помощи по уголовным делам регулируются Конвенцией о правовой помощи и правовых отношениях по гражданским, семейньм и уголовным делам, подписанной в Минске 22 января 1993 r. ${ }^{18}$, и двусторонними договорами. В ст. 6 Конвенции предусматривается объем правовой помощи (хотя перечень не является исчерпывающим). К хомпетенции органов внутрекних дел относятся следующие действия перечня: составление и пересылка докумектов; проведение обысков, изьятие, пересылка и выдача вещественных доказательств; проведение экспертизы; допрос сторон, обвиняемых, свидетелей, экспертов; уголовное преследование, розыск и выдача лиц, совершивших преступление. Стоит подчеркнуть, что прогрессивным положением Конвенции является порядок сношений учреждений юстиции непосредственно через центральные органы. В практике государств по заключению договоров о правовой помоши всегда отмечалось стремление установить такой порядок взаимоотношений органов государства, при котором отсутствовали промежуточные звенья. Такой порядок позволяет упростить пересьлху документов, освобождает промежуточное звено (или звенья) от определенной части работы, суть которой $\mathbf{X}$ их основной компетенции не относится.

В отношении Министерства внутренних дел России и органов других зарубежных государств действует другой порядок. Основаниями действий в данной области является договор о правовой помоши и правовых отношениях, заключенный между Россией и конкретным государством, а также установленный порядок взаимодействия при производстве уголовно-процессуальных действий, который определяет: «В случае необходимости производства отдельных следственных действий на территории зарубежного государства (допроса, опознания, выемки, обыска и т.д.) органы дознания, следствия (юстиции) обращаются в Управление по надзору за следствием и дознанием Генеральной Прокуратуры Российской Федерации с соответствующей просьбой о подтотовке международных следственных поручений в установленной форме» ${ }^{19}$. При этом поручение направляется прохуратурой в соответ- 
ствуюший орган прокуратуры (юстиции) запрашиваемого государства по дипломатическим каналам.

Первый порядок представляется более предпочтительным, и впоследствии следует стремиться $\mathrm{K}$ непосредственному сотрудничеству органов юстиции стран и устранению «промежуточных звеньев». На это обратил внимание Генеральный прокупор России Ю. Скуратов на проходившей 7 декабря 1995 г. пресс конференции, посвященной прошедшему совещанию генеральных прокуроров стран Содружества Независимых Государств. Государства заинтересованы в том, чтобы дела их граждан за рубежом решались местными органами, а не поднимались на дипломатический уровень, осложняя межтосударственные отношения ${ }^{20}$. Но надо учитывать, что в случае изменения порядка органы, осуществляющие сношения, должны быть укомплектованы квалифицированными сотрудниками, обладающими значительной подготовкой и знаниями не только в области национального права, но и международного права и международной этики. Вопрос о выборе органов, непосредственно исполняющих договоры о правовой помощи, решается каждым государством самостоятельно, но в любом случае этот порядок должен отвечать следующим требованиям: 1) способствовать быстрому и слаженному выполнению поручений; 2) гарантировать полноту и хорошее качество выполнения; 3) гарантировать охрану безопасности и суверенитета ках запрашиваемого, так и запрашивающего государства. Упрощение порядка сношений с органами уголовной юстиции других стран стало настоятельной необходимостью, так как сроки рассмотрения запросов из-за направления их через Генеральную Прохуратуру достигают 5-6 месяцев.

В отношениях мехду Россией и другими странами при отсутствии договора о правовой помощи обращение компетентных органов запрашивающего государства вообще не порождает для органов внутренних дел кихаких последствий. В таком случае Россия юридически не обязана предоставлять определенную информацию или совершать какие-либо процессуальные действия и может делать это лишь в порядке вежливости и на началах взаимности. Для органов внутренних дел обязательным будет лишь нормативный акт, принятый по этому поводу Правительством России.

\section{5. Экстрадиция как основной вид взаимной правовой помощи}

В качестве основного вида правовой помощи международные договоры обычно называют выдачу лиц, подозреваемых в совершении преступлений или осужденных $\mathrm{x}$ лишению свободы для при- 
ведения приговора в исполнение. Выдача преступника - это передача его государством, на территории которого он находится, другому государству, на территории которого это лицо считается совершившим преступление или осужденным за него для применения нахазания. Все договоры о правовой помощи содержат правила: невыдачи собственных грахдан; выдачи только за преступления, предусмотренные договором (чаще всего за преступления, совершение которых может повлечь по захонодательству обоих государств наказание в виде лишения свободы на срок не менее 1 года); невыдачи лиц, совершивших преступления на территории страны, к которой обрашено требование; невыдачи при истечении срока давности, наличии постановления о прекращении дела и иных захонных оснований; неприменении оговорки о выдаче политических преступнихов; обязательности возбуждения уголовного преследования по требованию другой стороны против собственных граждан, подозреваемых в совершении преступлений на ее территории.

Типовой договор о выдаче, разработанный и принятый Генеральной Ассамблеей ООН 14 декабря 1990 г., кроме того, предусматривает в качестве императивных оснований для отказа в выдаче следующие обстоятельства: «f) если лицо, в отношении которого поступает просьба о выдаче, было или будет подвергнуто в запрашивающем государстве пыткам или жестоким, бесчеловечным или унижающим достоинство видам обрашения или наказания или если это лицо в процессе судебного разбирательства не обладало и не будет обладать правом на минимальные гарантии в процессе уголовного разбирательства, предусмотренными в ст.14 Мехдународного пакта о гражданских и политических правах; g) если... осужденное лицо не имело достаточной возможности для обеспечения его защиты» (ст.3). Эти правила следовало бы включать в каждый мехдународный договор о правовой помощи. В принятой в 1993 году Конвенции о правовой помощи и правовых отношениях по гражданским, семейным и уголовным делам стран Содружества Независимых Государств положения Типового договора не учитываются, не устанавливается в ней и такое основание для отказа в выдаче, как политический характер преступления, что кажется нам значительным отступлением от положений ранее заключавшихся СССР мехдународных договоров.

Договоры подробно регламентируют вопросы содержания и формы документов о выдаче, порядок взятия под стражу лица, выдача которого требуется, и другие, связанные с ними. В случае коллизий, если требования о выдаче поступают от нескольких государств, вопрос разрешает запрашиваемое государство. Устав Международ- 
ного уголовного суда, разработка которого завершена на 46-й сессии Комиссии мехдународного права ООН, в ст.53 предусматривает по этому поводу, что государство - участник договора «по возможности отдает предпочтение просьбе Суда перед просьбами, поступившими от других государств». Хотя процедура выдачи в договорах не регулируется, этот вопрос решает Генеральная прокуратура. В процедуре выдачи следовало бы предусмотреть обязательное участие защитника, так как фахтически нарушается право обвиняемого на защиту. Соблюдение всех формальностей при выдаче, а также при совершении иных процессуальных действий необходимо, ибо в судебном заседании будет проверяться не только относимость дохазательств, но и их допустимость, то есть соответствие способов получения законодательно предусмотренным.

Международные договоры об обмене правовой информацией предусматривают обязательство обмена правовыми актами по вопросам, обозначенным в тематическом перечне нормативных актов, подлежащих межгосударственному обмену, прилагаемом $\mathbf{x}$ Договору. В 1992-1995 годах Россия заключила такие договоры с Арменией, Кыргызстаном, Грузией, Азербайджаном, Белоруссией, Ухраиной и подписала Многостороннее соглашение стран Содружества Независимых Государств. В протоколах $\mathrm{k}$ Соглашению и договорах в качестве организации, осуществляющей координащию работ по созданию эталонных баз данных и коммуникаций для межгосударственного обмена правовой информацией, со стороны России названо Государственно-правовое управление при Президенте РФ, со стороны друтих стран - министерства юстиции. Для российской стороны возложение этой обязанности на Министерство юстиции было бы более правильным. Согласно Положению о Главном государственно-правовом управлении Президента РФ 21 оно является самостоятельным подразделением Администрации Президента и в качестве его основных функций и задач межгосударственный обмен правовой информацией не называется.

\section{6. Дипломатическое право и деятельность ортанов внутренних дел}

Сотрудникам органов внутренних дел необходимо знание положений дипломатических и консульских конвенций. В этой области международного права действует Венская конвенция о дипломатических сношениях от 18 апреля 1961 г., Венская конвенция о консульских сношениях от 24 апреля 1963 г., Венская конвенция о представительстве государств в их отношениях с международны- 
ми организациями универсального характера от 14 марта 1975 г. и др. Дипломатические представительства защищают в государстве пребывания интересы аххредитуюшего государства и его грахдан (ст.3 Венской хонвенции о дипломатических сношениях 1961 г.). Права консулов по защите граждан ограничены узкой и определенной областью государственных интересов.

Наиболее подробно компетенция хонсульских долхностных лиц устанавливается в двусторонних консульских конвенциях или соглашениях. Все конвенции содерхат перечень привилегий консульских учреждений и консульских должностных лиц, $\mathbf{K}$ которым относятся: неприкосновенность личности консула и его семьи, иммунитет от уголовной юрисдикции государства пребывания, неприкосновенность помещений консульства и жилых помещений консульских должностных лиц, неприкосновенность официальной корреспонденции и архивов, средств передвижения. Кроме того, имеется ряд других привилегий. Так, глава хонсульского учрехдения и консульское должностное лицо не подлежат уголовной и административной юрисдикции властей в отношении действий, совершенных при выполнении консульских функций; если такое лицо имеет дипломатический паспорт, оно имеет право отказаться от дачи свидетельских показаний. Сотрудники консульского учрехдения и работники обслуживающего персонала хотя и могут быть вызваны для дачи свидетельских показаний, но в случае отказа к ним не могут применяться принудительные меры. Привилегии и иммунитеты не распространяются на сотрудников, работников обслуги и членов семей работников консульства, если они являются гражданами посударства пребывания или постоянно проживают в нем.

В консульских конвенциях говорится, что для выполнения своих консульских функций консульское должностное лицо может обращаться к компетентным местным властям консульского округа, а также в центральные органы государства пребывания в той степени, в какой это допускается законами, правилами, обычаями государства пребывания или соответствующими международными соглашениями. Объем такой помощи определяется в конкретном соглашении. Например, Консульская конвенция между СССР и Республикой Индия предусматривает, что «консульское должностное лицо может обращаться к компетентным властям государства пребывания за содействием в розыске пропавших без вести граждан представляемого государства, постоянно прохиваюших или временно находящихся на территории государства пребывания» $\left(\right.$ cт.38) ${ }^{22}$.

Власти государства обязаны уведомлять консула обо всех случаях ареста или задержания граждан представляемого государства (если эти действия совершены в пределах консульского округа). 
Консулу сообщается также обо всех случаях задержания, ареста, взятия под страху, если задержанный - грахданин аккредитующего консула государства - этого потребует. Некоторые конвенции не предусматривают срока сообщения об аресте или задержании, говоря лишь об уведомлении в кратчайшие сроки (Консульская конвенция между СССР и Республикой Индия, ст. 38), другие устанавливают определенный срок: например, по Консульской хонвенции мехду СССР и Турцией -5 дней ${ }^{23}$. Консульское должностное лицо имеет право немедленно или не позднее установленного срока посетить задержанного, арестованного или отбывающего наказание гражданина представляемого государства. Эти права осуществляются в соответствии с законами государства пребывания при условии, что они не аннулируют этих прав, то есть в случае, если национальное законодательство не будет предусматривать такие права, применяются непосредственно нормы конвендии.

Консульское должностное лицо имеет право без ущерба для прав государства пребывания расследовать любое происшествие, имевшее место во время плавания судна представляемого государства. В большинстве конвенций установлено, что правила, касающиеся судна представляемого государства, в равной мере применяются и к его воздушным судам. Договоры проводят разграничение юрисдикции государства пребывания в отношении происшествий на судах. Так, ст.17 Консульского договора между СССР и КНР гласит: «Кроме как по просьбе капитана или консульского должностного лица или с их согласия компетентные власти государства пребывания не могут вмешиваться во внутренние дела судна представляемого государства» 24 .

По смыслу двусторонних консульских конвенций консул может обратиться за помощью в расследовании преступления $\mathbf{K}$ местньм властям, которые будут руководствоваться при проведении расследования национальным законодательством. Однако после окончания расследования местным судом дело не рассматривается. Для всех полученных в результате документов будет необходима консульская легализация, то есть подлинность подписей на любом акте и документе, составленном в пределах консульского округа, заверяется подписью и печатью консула.

Некоторые конвенции содержат перечень случаев, когда соответствующие органы государства пребывания могут предпринимать принудительные меры в отношении преступных действий, совершенных на борту судна представляемого государства. Статья 50 Консульской конвенции между СССР и Турцией предусматривает следуюшие основания для этого: «а) преступные действия совершены грахданином государства пребывания или против него, либо 
преступные действия совершены лицом, не являющимся членом экипажа или против него; б) преступные действия нарушают порядок или безопасность территории или внутренних вод либо порта государства пребывания; в) преступные действия нарушают захоны и правила государства пребывания, касающиеся охраны здоровья, обеспечения безопасности на море, иммиграционного и таможенного режима, предотвращения загрязнения моря нефтью и хонтрабанды; г) преступные действия влекут за собой наказание в виде лишения свободы не менее 3 лет и более по законам государства пребывания» ${ }^{2}$. Если расследование начато компетентными властями государства пребывания на борту судна, об этом уведомляется консул до начала осуществления принудительных действий либо, если это было невозможно, в иной как можно более краткий срок.

Определенные нюансы деятельности сотрудников органов внутренних дел могут быть обусловлены и международными договорами, регулирующими торговое судоходство. Эти соглашения обычно предусматривают исключение из юрисдикции государства пребывания экипажей иностранных судов. Например, Соглашение между Правительством РФ и Правительством Республики Грузия о торговом судоходстве в ч. 2 , ст. 10 , устанавливает: «Если член экипажа судна одной из Договаривающихся Сторон совершит правонарушение на борту судна во время пребывания судна во внутренних водах государства другой Договаривающейся Стороны, то компетентные органы этой Договаривающейся Стороны не привлекают его $\mathbf{k}$ ответственности без согласия дипломатического или хонсульского должностного лица» ${ }^{26}$. Не подпадающие под это правило случаи специально оговариваются в договоре. Обо всех случаях совершения правонарушений на судне хомпетентные органы государства по просьбе капитана судна извещают дипломатическое или консульское лицо до принятия каких-либо мер или когда такие меры принимаются и способствуют установлению контакта мехду указанным должностным лицом и экипажем судна.

\section{7. О межведомственных соглашениях как правовьх основах деятельности органов внутренних дел}

Для более действенного сотрудничества заключаются также соглашения между правительствами или министерствами внутренних дел стран о сотрудничестве в борьбе с преступностью или ее отдельными проявлениями. Такие соглашения заключаются как со странами, с которыми заключены договоры о правовой помощи, так и с государствами, в отношениях с которыми таких договоров 
нет. Например, Соглашение между МВД Российской Федерации и МВД Итальянской Республики о сотрудничестве в борьбе с организованной преступностью и незаконным оборотом наркотических средств и психотропных веществ от 11 сентября 1993 г. $^{27}$, Соглашение о сотрудничестве между МВД РФ и МВД Республики Грузия от 21 марта 1994 r. ${ }^{28}$, Соглашение между МВД Российской Федерации и МВД Туркменистана о сотрудничестве в борьбе с организованной преступностью от 18 мая 1995 г. $^{29}$, Соглашение между Правительством РФ и Правительством США о сотрудничестве по уголовно-правовым вопросам ${ }^{30} .24$ сентября 1993 г. министерства внутренних дел стран СНГ заключили Соглашение о сотрудничестве в вопросах возвращения несовершеннолетних в государства их проживания, Соглашение в сфере обеспечения безопасности дорожного движения, а 17 февраля 1994 г. были захлючены соглашения, предусматривающие сотрудничество в области борьбы с организованной преступностью, сопровождения и охраны ОВД (полицией) ценных и специальных грузов, перевозимых по территории других государств, транзитной перевозки лиц, взятых под стражуз

В 1995 году Прокуратурой РФ разработаны три типовых договоpa: «O передаче осужденных $\mathrm{k}$ лишению свободы для дальнейшего отбывания наказания», «О выдаче преступников» и «О передаче страдающих психическим расстройством для проведения принудительного лечения». 19 января 1996 г. на Совете глав государств СНГ был рассмотрен вопрос о сотрудничестве в области борьбы с преступностью и решено внести проекты типовых договоров на рассмотрение следующего Совета. Договор о выдаче значительно отличается от Конвенции, в нем учтены предложения Конгресса ООН по предупреждению преступности и уголовному правосудию 1995 года, в качестве условия выдачи предусмотрено обязательное письменное заявление осужденного о его согласии на выдачу для отбывания нахазания. На март 1996 года Россией были захлючены договоры о передаче осужденных для отбывания наказания с Азербайджаном, Латвией, Туркменистаном и Финляндией. Кроме того, Россия является участницей Конвенции о передаче лиц, осужденных K лишению свободы, для отбывания наказания в государстве, гражданами которого они являются, подписанное в Берлине представителями Болгарии, Венгрии, ГДР, КНДР, Кубы, МНР, ПНР, СССР, Чехословакии и ратифицированной в нашей стране 26 августа 1979 г. $^{32}$ Договор о передаче психически больных устанавливает, что осужденный больной передается в страну грахданства, если эта страна имеет условия для его лечения. В качестве меры его безопасности оговаривается невозможность привлечения его $\mathbf{k}$ ответственности за деяние, в отношении которого он был признан 
невменяемым. Подписание этих договоров между странами Содружества Независимых Государств поставит массу вопросов. Для органов внутренних дел возникнут проблемы: передача осужденных граждан стран Содружества в страну гражданства возможна только с их согласия и по просьбе государства гражданства; большинство государств Содружества не имеют условий для лечения психически больных, следовательно, разгрузить уголовно-исполнительную систему будет задачей сложной.

\section{8. О мехдународных стандартах для органов внутреннкх дел}

В последнее время много говорится о международных стандартах, правилах, руководящих положениях в области деятельности органов внутренних дел. Главным образом в них идет речь о принципах и правилах поведения долхностных лиц и защите прав граждан, а также правах заключенных и задержанных. Международные стандарты - нормы чисто рекомендательного характера. Применять их или нет - решает государство. Оно может опираться на их положения при создании национальных законодательных актов, и речь идет лишь о степени соответствия, нап̆ример, Минимальных стандартных правил обращения с заключенными, Кодекса поведения долхностных лиц по поддержанию правопорядка и российского захонодательства в этой области. Захонодатель может использовать идеи, заложенные в этих документах, облекая их в форму нормативно-правовых актов. Это стремление имеет морально-политический характер. Хотя принятые стандарты и правила юридической силы не имеют, но отражают требования общедемократической морали, в их выработке и принятин участвуют также и представители России. Примером использования идей мехдународных стандартов является воплощение типовых требований $\mathbf{K}$ сотрудникам органов уголовной юстиции, установленных в Кодексе поведения долхностных лиц по поддержанию правопорядка в нормах Российской Конституции и законов. При рассмотрении этих документов не стоит забывать, что и многие международные стандарты принимаются под влиянием прогрессивных норм национального, и российского в том числе, законодательства. Международные стандарты в систему правовых основ формирования и деятельности органов внутренних дел не входят, однако идеи этих документов должны использоваться, особенно в области деятельности пенитенциарной системы. 
Подводя итог исследования, заметим, что общепризнанные принципы и нормы международного права пока слабо осознаются в науке и на практике как элемент правовых основ формирования и деятельности органов внутренних дел. Процесс взаимодействия международно-правовых и внутригосударственных элементов правовых основ формирования и деятельности органов внутренних дел находится в настоящее время в начальной стадии. Об их взаимозависимости (в целом) можно говорить с достаточной степенью условности. Однако, что касается международных договоров о правовой помощи и мехдународных договоров об экстрадиции, здесь взаимосвязь и взаимозависимость с внутригосударственным правом прослеживается вполне четко. Общепризнанные принципы и нормы международного права осуществляются наряду с законами. И все же в связи с тем, что деятельность Министерства внутренних дел обеспечивает внутреннюю стабильность и безопасность государства, такого рода правовые установления должны осуществляться с помощью специальных процедур. Кроме того, в связи с участием сотрудников органов внутренних дел, служащих внутренних войск в миротворческих операциях и в борьбе с бандформированиями (участие в разрешении внутригосударственных конфликтов) настоятельной необходимостью являются введение для слушателей учебных заведений системы Министерства внутренних дел специального курса по международному гуманитарному праву (правила и обычаи ведения войны) и рассмотрение темы соотношения внутригосударственного и международного права при изучении общей теории права и государства.

1 См. Мкллерсон Р.A. Соотношение и взаимодействие международного публичного, международного частного и национального права (автореферат). - М., 1985 . - C. 45.

${ }_{2}$ См. Камаровский Л.А. Основные вопросы науки мехдународного права. - М., 1892. - C. 65.

3 См. Тункин Г.И. Теория международного права. - М., Международные отношения. - 1970. - С. 179

4 См. Мюллерсон Р.A. Указ.соч. - С. 69.

5 Краткий словарь по философии. - М., 1982. - С. 39.

6 См. Баскин Ю.Я., Фельдман Д.И. Нстория международного права. - М., Международные отношения. - 1990. - С. 179.

7 Камаровский Л.A. Основные вопросы науки международного праBa. - C. 55 .

8 $\mathrm{CM}$ Дмитриева Г.К. Взаимодействие морали и международного права (автореферат). - М., 1991. - С. 167.

๑ Мюллерсон Р.A. Указ.соч. - С. 132.

10 С. Лукашук И.И. Международное право в судах государств. СПб., 1993. - С. 48, 49. 
1 См. Картаикин В.A. Права человеха в мехдународном и внутригосударственном праве (ИГТРРАН). - М., 1995. - С. 10.

12 Шершеневич Г.Ф. Общее учение о праве и государстве. - М., 1991. - C. 25.

13 См. Лукашук И.И. Международное право в судах посударств. СПб., 1993. - С. 106.

14 Российская газета. - 1995. - 21 июля.

is Международная защита прав и свобод человека. Сборник документов. - М., Юридическая литература. - 1990. - С. 32-53, 125-140.

16 Международная защита прав и свобод человека. Сборник документов. - М., Юридическая литература. - 1990. - С. 35, 404.

17 Данные представлены МВД Конференции по применению международного права правоохранителҺными органами РФ, проходившей 7-9 февраля 1996 г. в г. Москве.

18 Сборник мехдународных договоров Российской Федерации по охазанию правовой помощи. - М., изд-во «СПАРК». - 1996. - С. $26-52$.

19 Интерпол-Информ. - М., 1994. - С. 165-167.

20 См. Лукаиук И.И. Международное право в судах государств. СПб., 1993. - С. 7.

21 Российская газета. - 1996. - 19 марта.

22 Сборник международных договоров. - Bыn. XLIII. - 1989. -№ 4301 .

${ }_{23}$ Сборник международных договоров. - Вып. XLY. - 1991. 一 № 4535. - Ст. 43.

24 Сборник международных договоров. - Вып. XLIII. - 1989. № 4302.

25 Сборник международных договоров. - Вып. XLY. - 1991. № 4535 .

26 Российская газета. - 1996. - 27 aпр.

27 Вестник МВД РФ. - 1994. - № 1.

28 Вестник МВД РФ. - 1994. - № 6.

29 Вестник МВД РФ. - 1995. - № 6.

30 Сборник международных договоров РФ по оказанию правовой помощи. - М., изд-во «СПАРК». - 1996. - С. 465-471.

31 Вестник МВД РФ. - 1994. - № 3, 5.

32 Сборних международных договоров РФ по оказанию правовой помощи. - М., изд-во «СПАРК». - 1996. 